\title{
15. OLIGOCENE AND MIOCENE VEGETATION IN HIGH LATITUDES OF THE NORTH ATLANTIC: PALYNOLOGICAL EVIDENCE FROM THE HOVGÅRD RIDGE IN THE GREENLAND SEA (SITE 908) ${ }^{1}$
}

\author{
M.C. Boulter ${ }^{2}$ and S.B. Manum ${ }^{3}$
}

\begin{abstract}
The organic assemblages (pollen, spores, dinoflagellate cysts, plant debris) extracted from Oligocene and upper Miocene sediments of the Hovgård Ridge (Ocean Drilling Program Site 908) are dominantly of terrestrial origin. With its present position in the middle of the Fram Strait (Greenland Sea), an obvious source for these terrestrial fossils is lacking. However, they are in full consistency with the tectonic model for the ridge's origin as a sliver rifted from the Svalbard Platform since anomaly 13 time. The dominance of pollen and plant tissue fragments (often $>100 \mu \mathrm{m}$ ) and the low proportion of dinoflagellate cysts (usually $<20 \%$ ) indicate relatively short distances to a forested lowland with prolific humic productivity. The pollen flora in the Hovgård Ridge sediments present a unique glimpse into previously unknown vegetation in high northern latitudes during middle Oligocene and late Miocene times. The pollen indicates forests of conifers related to Pinus, Picea, Tsuga, and Taxodium, with a minor element of angiosperms but relatively common ferns. This is different from the well-known Paleocene-Eocene floras on adjacent Spitsbergen that were also rich in conifers but had a richer and more diverse angiosperm element and lacked Tsuga relatives. It is a surprising observation that there is no change reflected in the pollen from the Oligocene to the upper Miocene.
\end{abstract}

\section{INTRODUCTION}

In this paper we present the results of our pollen analysis of preparations from 38 samples through $180 \mathrm{~m}$ of Tertiary sediments from Ocean Drilling Program Hole 908A (Cores 151-908A-18X-2 to 37X2; Table 1) and discuss their paleobotanical and paleoenvironmental implications. The section we studied represents two lithologic units, of middle Oligocene and late Miocene age, separated by an unconformity.

The Hovgård Ridge is a prominent southeast-northwest-trending topographic feature about $150 \mathrm{~km}$ in length in the deep, central part of the Greenland Sea just north of $78^{\circ} \mathrm{N}$ latitude (Figs. 1,2). The ridge rises abruptly to an elevation of more than $1,000 \mathrm{~m}$ above the average seafloor depth of $2,500-3,000 \mathrm{~m}$. Today it is $200 \mathrm{~km}$ west of Spitsbergen, but a model for the plate tectonic evolution of the western Svalbard Margin interprets the ridge as a sliver rifted from the Svalbard Platform after the Eocene-Oligocene transition (anomaly 13 time; Myhre and Eldholm, 1988; Figs. 3, 4). The ridge has a major influence on the present deep-water circulation through the Fram Strait, and Site 908 was drilled with the objective of studying the nature and age of the sediments in order to gain a better understanding of the origin and history of the ridge and its paleoceanographic significance for the evolution of the Arctic-Atlantic gateway.

Our palynological analysis of the sediments shows dominantly fresh-looking plant debris and pollen, which indicate a near terrestrial source. Fragments of leaf cuticle and other debris often exceed 100 $\mu \mathrm{m}$ in diameter, and the low proportions of dinoflagellate cysts (rarely exceeding 20\%; Fig. 5) are further indications of only some tens of kilometers distance from land with plant cover and high production of humic material.

'Thiede, J., Myhre, A.M., Firth, J.V., Johnson, G.L., and Ruddiman, W.F. (Eds.), 1996. Proc. ODP, Sci. Results, 151: College Station, TX (Ocean Drilling Program). ${ }^{2}$ Palaeobiology Research Unit, University of East London, London E15 4LZ, United Kingdom. boulter@uel.ac.uk

'Institute of Geology, P.O. Box 1047, Blindern, N-0316 Oslo 3, Norway.
The pollen preserved in the Hovgård Ridge sediments offers a unique opportunity for a glimpse into a high latitude Northern Atlantic flora from middle Oligocene (late Rupelian-early Chattian) and late Miocene times. While Paleocene and Eocene floras of the Arctic, and of Spitsbergen in particular, are well documented (see papers in Boulter and Fisher [1994] for references), well-dated Oligocene and younger Tertiary floras of middle to high $70^{\circ}$ northern paleolatitudes were previously unknown. The aim of this paper is to document and interpret the pollen evidence, to compare it with other Paleogene floras of the region and to discuss the paleophytogeographic and paleoclimatic implications. Previously, no significant change in the vegetation of the Svalbard region had been documented through much of the early Tertiary (Manum, 1994), so it was not possible to make biostratigraphic use of either leaf floras or the pollen and spore assemblages to determine the age of the sediments. That raises once again the possibility first raised by Livshits (1974) that some of the plant beds on Spitsbergen may be of Oligocene age.

\section{MATERIALS AND METHODS}

Hole 908A was drilled on the northwestern crest of the Hovgård Ridge (Fig. 2). Total penetration was about $345 \mathrm{~m}$, with $91.1 \%$ recovery. The basal $158 \mathrm{~m}$ of the sediments, from Core 151-908A-21X down, have been dated by dinoflagellate cysts as late Rupelian to early Chattian (Fig. 6; Poulsen et al., this volume). At $185 \mathrm{mbsf}$ there is a major hiatus with upper upper Oligocene and lower and middle Miocene sediments missing from the section (between Sections 151908A-20X-5 and 20X-CC of the present study).

The present study is based on 29 samples through the Oligocene section (Sections 151-908A-20X-CC to 37X-2) and nine samples from the lowermost $25 \mathrm{~m}$ immediately above the hiatus (Core 151908A-18X-2 to 20X-5). Sampling density varies between one and four samples for each $9.5 \mathrm{~m}$ core. Samples of 2 to $3 \mathrm{~cm}^{3}$ were subjected to standard palynological processing, using hydrochloric and hydrofluoric acids but no oxidation. The organic residues were sieved through a $20-\mu \mathrm{m}$ net before slide mounting, but two slides were made before sieving to record the entire organic assemblage. 
Table 1. Pollen counts in 38 samples studied, Hole 908A.

\begin{tabular}{|c|c|c|c|c|c|c|c|c|c|c|c|c|c|c|c|c|c|c|c|c|c|c|c|c|}
\hline $\begin{array}{l}\text { Core, } \\
\text { section }\end{array}$ & 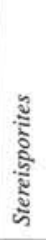 & 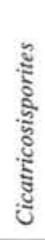 & 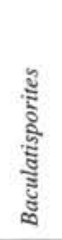 & 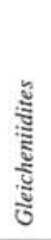 & 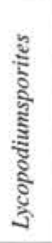 & 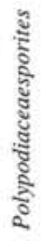 & 气ั๊ & 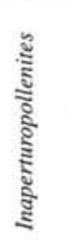 & 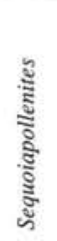 & 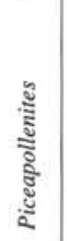 & 气ั๊ & 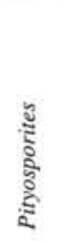 & 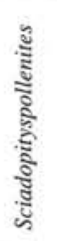 & 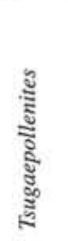 & 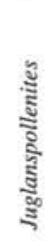 & 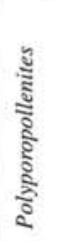 & 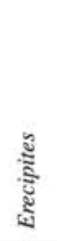 & 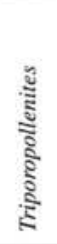 & है & 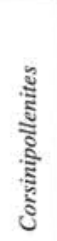 & ָั & $\begin{array}{l}\text { E } \\
\bar{E} \\
\text { ఏ } \\
\overline{\overline{0}}\end{array}$ & 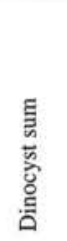 & 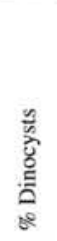 \\
\hline $18 \mathrm{X}-2$ & & & 2 & & 1 & 1 & 2 & & & 2 & 7 & 56 & & & & & & & & & & 71 & 14 & 16.5 \\
\hline $18 X-5$ & & & 8 & & 4 & 2 & 2 & & & 2 & 6 & 78 & & & & & & & & & & 100 & 20 & 16.7 \\
\hline $18 \mathrm{X}-6$ & & & & & 6 & 2 & 4 & & & & & 38 & & & & & & & & & 6 & 56 & 13 & 18.8 \\
\hline $19 \mathrm{X}-4$ & & & & & 2 & & & & & & & 18 & & & & & & & & & & 20 & 20 & 50.0 \\
\hline $19 X-5$ & & & 6 & & 4 & 8 & & & & 6 & & 24 & & & & & & & & & & 48 & 16 & 25.0 \\
\hline $19 \mathrm{X}-\mathrm{CC}$ & 4 & & 12 & & 12 & 8 & 16 & & & 12 & 52 & 144 & & 8 & 1 & & & & 1 & 1 & & 271 & 72 & 21.0 \\
\hline $20 \mathrm{X}-2$ & 2 & & 6 & & 6 & 4 & 8 & & & 6 & 26 & 72 & & 4 & & & & & & & & 134 & 36 & 21.2 \\
\hline $20 X-4$ & & & 12 & & 4 & 2 & 8 & & & 10 & 20 & 210 & & & & & 8 & & & & & 274 & 20 & 6.8 \\
\hline $20 \times-5$ & & & & 15 & & 6 & & & & 39 & 60 & 450 & 3 & 9 & & & & & & & & 582 & 63 & 9.8 \\
\hline $20 \mathrm{X}-\mathrm{CC}$ & 10 & & 70 & 30 & 50 & 60 & 110 & & & 60 & 100 & 950 & 40 & 100 & & 10 & 20 & 10 & & & & 1620 & 40 & 2.4 \\
\hline $21 \mathrm{X}-1$ & 6 & & 20 & 6 & 8 & 28 & 16 & & & 10 & 6 & 184 & 2 & 2 & & & & & & & & 288 & 30 & 9.4 \\
\hline $22 \mathrm{X}-1$ & & & 54 & 10 & 4 & 16 & 4 & 4 & & 2 & 2 & 114 & 4 & 10 & & & 4 & & & & & 228 & 16 & 6.6 \\
\hline $22 \mathrm{X}-4$ & & & 2 & 8 & & & 20 & 2 & & & 6 & 84 & & & & & & 2 & & & & 124 & 14 & 10.1 \\
\hline $23 \mathrm{X}-1$ & 4 & & 16 & 8 & 8 & & 52 & & & 8 & & 180 & 8 & 16 & & 8 & 4 & & & & & 312 & 11 & 3.4 \\
\hline $24 \mathrm{X}-1$ & & & 12 & 6 & 4 & 16 & 12 & & & 6 & 20 & 170 & & 2 & & & 2 & & & & & 250 & 18 & 6.7 \\
\hline $25 \mathrm{X}-4$ & & & 42 & 2 & 2 & 12 & 10 & 4 & & 14 & 14 & 210 & 4 & 10 & & & 2 & & & & & 326 & 50 & 13.3 \\
\hline $25 \mathrm{X}-6$ & 5 & & 25 & 10 & 5 & 25 & 30 & & & 55 & 60 & 250 & 15 & 21 & & & & & & & & 501 & 85 & 14.5 \\
\hline $26 \mathrm{X}-1$ & & & 104 & 4 & 48 & 60 & 48 & 8 & & 40 & 132 & 380 & 16 & 60 & & & & & 1 & & & 901 & 56 & 5.9 \\
\hline $26 \mathrm{X}-4$ & & & 24 & 8 & $\begin{array}{r}40 \\
4\end{array}$ & 12 & $\begin{array}{l}40 \\
24\end{array}$ & & & & 72 & 160 & 4 & 4 & & & & & I & & 1 & 313 & 132 & 29.7 \\
\hline $27 \mathrm{X}-4$ & & & 65 & 2 & 5 & 30 & 5 & 5 & & 35 & 100 & 500 & 5 & 25 & & 1 & & & 1 & & & 779 & 100 & 11.4 \\
\hline $28 \mathrm{X}-1$ & & & 16 & 4 & 8 & 20 & 15 & 12 & & 15 & 32 & 140 & 4 & 4 & & & & & & & & 270 & 12 & 4.3 \\
\hline $28 \mathrm{X}$ & & & 45 & 5 & & 15 & 35 & 10 & & 50 & 80 & 375 & 20 & 30 & 8 & 3 & & & & & & 676 & 28 & 4.0 \\
\hline $29 \mathrm{X}-3$ & & & 45 & 25 & 25 & 30 & 40 & & & 40 & 96 & 550 & 5 & 25 & & 1 & & & & & & 882 & 25 & 2.8 \\
\hline $30 \mathrm{X}-1$ & & & 30 & 5 & 10 & 20 & 35 & & & 40 & 75 & 350 & 2 & 40 & & i & & & & & & 608 & 31 & 4.9 \\
\hline $30 \mathrm{X}-2$ & & & 30 & 5 & 5 & 15 & 20 & 15 & & 50 & 40 & 340 & 20 & 20 & & & & & & & & 560 & 64 & 10.3 \\
\hline $30 \mathrm{X}-3$ & & 1 & 32 & & 8 & 12 & 32 & & & 28 & 72 & 208 & 8 & 32 & & 1 & & & & & & 434 & 68 & 13.5 \\
\hline $30 \times-4$ & & & 48 & 4 & 4 & 12 & 20 & 8 & & 56 & 100 & 320 & 8 & 24 & & 2 & & & & & & 606 & 31 & 4.9 \\
\hline $31 X-4$ & 12 & 8 & 140 & 12 & 48 & 68 & 60 & $\begin{array}{l}\circ \\
4\end{array}$ & & 40 & 64 & 360 & $\stackrel{\circ}{12}$ & 24 & 4 & 28 & 12 & 4 & & & & 900 & 4 & 0.4 \\
\hline $32 \times-4$ & 12 & 0 & 40 & 1 & $\begin{array}{l}40 \\
10\end{array}$ & $\begin{array}{l}00 \\
15\end{array}$ & $\begin{array}{l}15 \\
15\end{array}$ & 20 & & 45 & $\begin{array}{l}04 \\
40\end{array}$ & 285 & $\begin{array}{l}12 \\
15\end{array}$ & 11 & 4 & 2 & 3 & 2 & & & & 504 & 105 & 17.2 \\
\hline $33 \mathrm{X}-1$ & & & 8 & & & 16 & 24 & & & 4 & 32 & 224 & 16 & 16 & & & 4 & & & & & 344 & 40 & 10.4 \\
\hline $33 \mathrm{X}-4$ & & & 36 & 4 & & 12 & & 4 & & 8 & 36 & 160 & 8 & 12 & & & & & & & & 280 & 48 & 14.6 \\
\hline $34 \mathrm{X}-3$ & & & 40 & 8 & 8 & 36 & 8 & & 1 & 52 & 76 & 400 & 8 & 20 & & 8 & 4 & 1 & & & & 670 & 120 & 15.2 \\
\hline $35 X-3$ & & & 32 & & & 8 & 8 & 28 & & 28 & 36 & 204 & 4 & 16 & & 3 & & & & & & 367 & 72 & 16.4 \\
\hline $36 \mathrm{X}-2$ & & & 60 & & 4 & $20^{\circ}$ & 20 & $\begin{array}{r}20 \\
4\end{array}$ & & 112 & $\begin{array}{r}50 \\
8\end{array}$ & 216 & $\begin{array}{r}4 \\
16\end{array}$ & 24 & & & & & & & & 484 & 28 & 5.5 \\
\hline $6 x-4$ & & & 28 & & 4 & 4 & 20 & & & 40 & 36 & 25 & $\begin{array}{r}10 \\
4\end{array}$ & 8 & & 8 & & 8 & & & & 412 & 60 & 12.7 \\
\hline $36 \times-5$ & 6 & & 24 & 4 & & 8 & 16 & 4 & & 28 & 28 & 172 & 8 & 8 & 1 & 5 & 4 & & & & & & 28 & 8.3 \\
\hline & & & 36 & 4 & 4 & 24 & 20 & 4 & & 44 & 36 & 276 & 16 & 40 & i & 2 & & 4 & & & & 511 & 72 & 12.3 \\
\hline $37 \mathrm{X}-2$ & 4 & 8 & 88 & 16 & 8 & 80 & 28 & 4 & & 20 & 28 & 540 & 4 & 20 & 8 & 1 & 8 & 3 & & & & 868 & 32 & 3.6 \\
\hline
\end{tabular}

\section{INTERPRETATION OF THE ORGANIC ASSEMBLAGES}

All samples contain abundant pollen, spores, and plant debris. The large pieces of well-preserved debris indicate that they could not have been transported far. The bulk of the pollen is equally freshlooking, and we cannot escape the conclusion that the assemblages are composed, for the overwhelming part, of material that has not been reworked. Furthermore, there is a stratigraphic consistency in the palynological composition throughout the section studied, which indicates a coeval source of plant litter and pollen that appears to have been a lowland with swamp forests. However, most of the samples do have a small number of less well preserved pollen and spores, and there are rare reworked dinocysts of Paleocene to Eocene age.

In the Oligocene section, the dinocysts rarely exceed $20 \%$ of total palynomorphs (Fig. 5) and are generally much less abundant, indicating a marginal marine environment. Fluctuations in the dinocyst percentages indicate changes in the distance to the terrestrial source. Two parts of the Oligocene section (Sections 151-908A-32X-4 to $35 \mathrm{X}-3$ and $25 \mathrm{X}-4$ to $27 \mathrm{X}-4$ ) give signals of deeper submersion, with more dinocysts, and very little angiosperm except likely saltmarsh forms at the top of the lower interval (provided our paleoecological interpretation of "Polyporopollenites" is right). In the Miocene part of the section, dinocyst percentages are somewhat higher, indicating a stronger marine influence or distance to shore. Some of the samples contain fusinitic particles and evidence of reworking, but the overall impression of first cycle organic deposition is the same as below the unconformity.
A plate tectonic model (Karlberg, 1995) advocates a relatively late separation of the Hovgård microcontinent from the Svalbard Platform (Fig. 4). This implies that a terrestrial source some tens of kilometers to the east of Site 908 is a valid site for the origin of the pollen and the palynodebris in the Oligocene section. The fluctuating marine/terrestrial palynomorph ratio probably reflects tectonically induced vertical movements of the microcontinent, and the hiatus is most likely the result of a late synrift uplift that caused erosion and nondeposition (A. Myhre, pers. comm., 1995). For the Miocene section, an elevated part of the microcontinent itself, with its vegetation, is a likely source area (see Poulsen et al., this volume, for further discussion).

\section{COMMENTS ON THE MAIN SPORE AND POLLEN TYPES}

The pollen and spore form-genera discussed below are names given to similar-looking specimens also present in older assemblages described from Spitsbergen (Manum, 1962) and the Brito-Arctic Igneous Province (Boulter and Manum, 1989) where they are fully illustrated. The plate numbers below refer to those in Manum (1962). The results of the pollen counts are given in Table 1 and Figure 7.

Cicatricosisporites

These spores are usually darker brown than most other palynomorphs in the preparations and are likely to have been reworked from older strata; most seem to be from Cretaceous taxa.

Baculatisporites (plate III, 1-4, 11-13) 


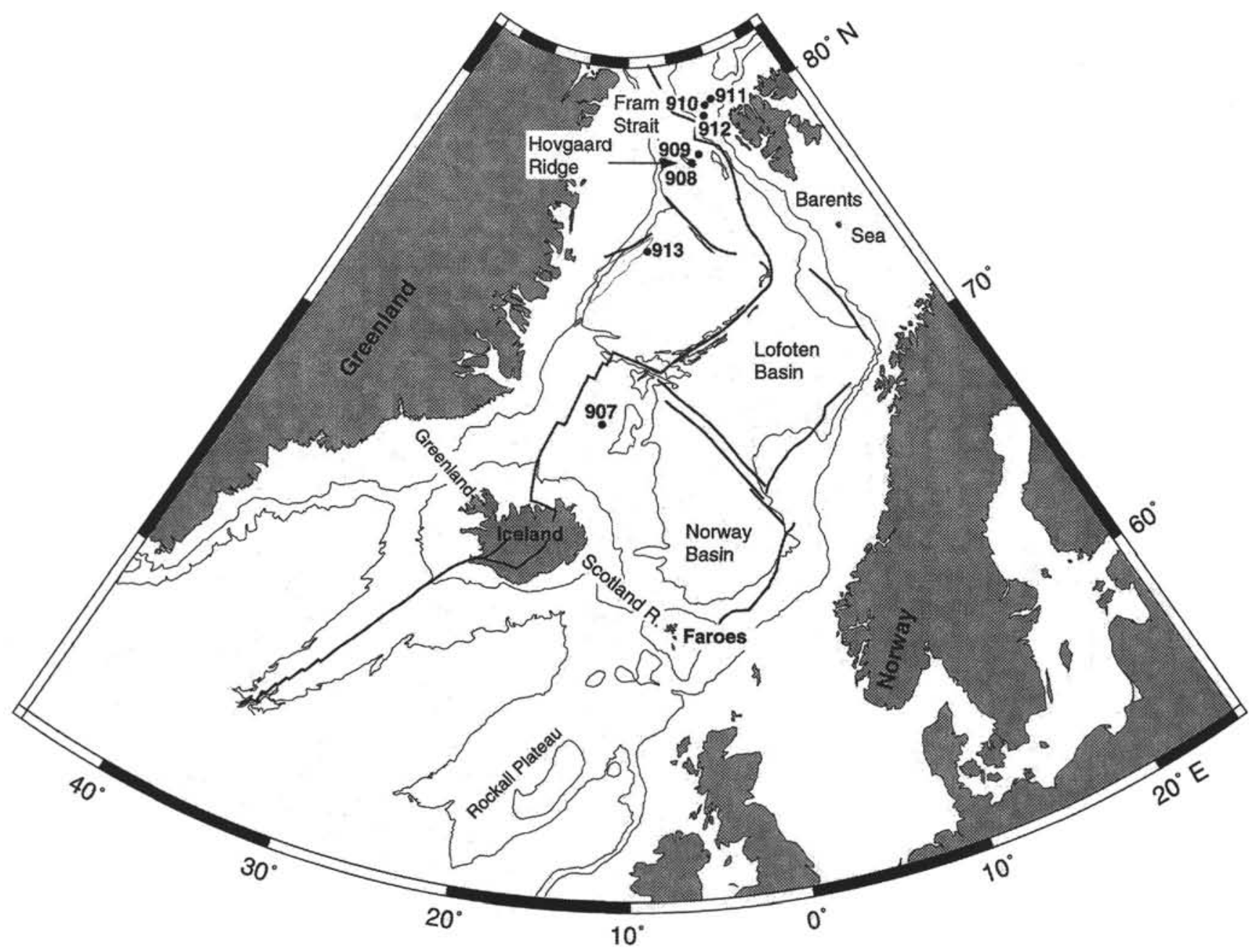

Figure 1. Site map showing position of the Hovgård Ridge in the Fram Strait and Site 908. Main plate tectonic structures are shown.

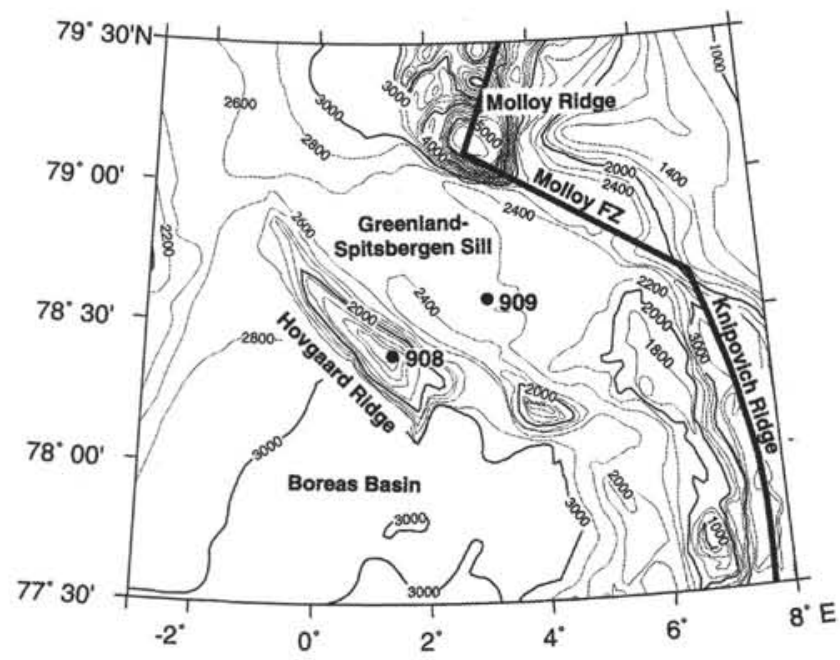

Figure 2. Bathymetry (in meters) of the Fram Strait around the Hovgård Ridge and Site 908 with major plate tectonic structures indicated (modified from Karlberg, 1995)
Baculate spores are present in most of the samples studied with clear baculae and trilete marks, and are often broken open. They may be related to ferns of the Osmundaceae, which are well represented in Arctic floras.

Gleicheniidites, Lycopodiumsporites, Polypodiaceaesporites, and Cyathidites its.

These spores are well known from the Tertiary and earlier depos-

\section{Sequoiapollenites}

Only one specimen of this papillate pollen has been found in the preparations. Although it may be a morphological variation of inaperturate Taxodiaceae pollen, there is a view (based on comparisons with the pollen of modern Taxodiaceae) that it represents the inland redwood lineage of that family rather than the lowland swamp species.

Inaperturopollenites (plate XI, 12-13)

Although usually associated with taxodiaceous swamp taxa, these pollens are less frequent than usual for swamp deposits, and are of quite variable form.

Sciadopityspollenites (plate XI, 1-9)

This distinct pollen is usually found in the northern Tertiary with Taxodiaceae and Tsuga-type.

Tsugaepollenites (plate X, 1-4) 


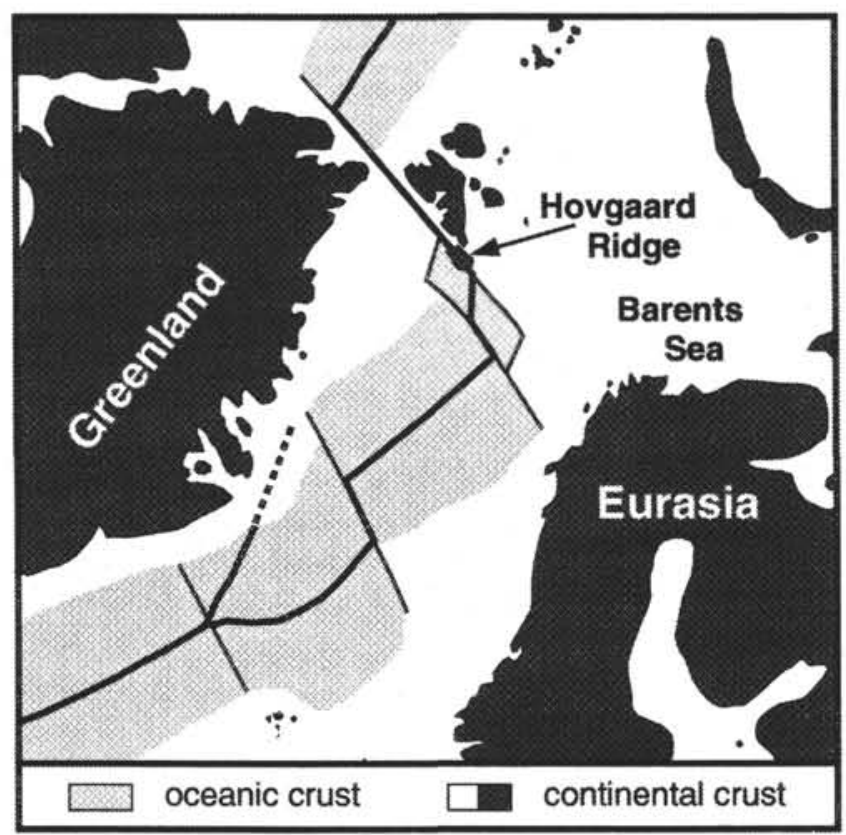

Figure 3. Diagrammatic plate tectonic reconstruction of the northernmost Atlantic and adjacent Arctic Ocean at Anomaly 13 time (Eocene/Oligocene transition) showing the position of the Hovgård Ridge. Modified from Eldholm et al. (1984).

There are many well-preserved examples of this important Arctic conifer. Today forms thought to be related are found with pines on upland slopes and favor high humidity and shade. They are also present south of the Arctic.

Piceapollenites (plate VI, 1-2; plate XIX, 1-3; plate XVII, 1-5)

These large bisaccates may be from species of Picea and Abies, possibly extinct.

Cedripites

Usually these small bisaccates are thought to have affinity with modern species of Cedrus-like plants that today enjoy dry climate.

Pityosporites (plate IX, 1-8)

These most common of all bisaccate pollen are from a variety of pine species, and there is no evidence they are extant. Like their relatives they produced pollen in large quantities that were well equipped for long-distance dispersal in the air and water.

Pterocaryapollenites (plate XVI, 11-12)

These 5-8 pored pollen are common in north temperate Tertiary assemblages.

Polyporopollenites

These multiporate, reticulate pollen may be from salt-marsh plants in the family Chenopodiaceae. Here they are the most common angiosperm pollen, especially in the sample from Section 151-908A$31 \mathrm{X}-4$ (around $288 \mathrm{mbsf}$ ).

Juglanspollenites (plate XVI, 13-14)

Juglandaceous leaves have been identified from Spitsbergen by Schloemer-Jäger (1958), Budhantsev (1983), and Kvacek et al. (1994).

Alnipollenites (plate XVI, 1-10)

Leaves that Kvacek et al. (1994) identified as Corylites hebridicus may be from plants producing this pollen.

\section{Intratriporopollenites}

There are two specimens of this Tilia-like pollen with very characteristic pores, both in Core 151-908A-20X (20X-6, 137-138 cm, and $20 \mathrm{X}-\mathrm{CC}$ ). Leaves thought to be associated with that family are identified from Spitsbergen by Kvacek et al. (1994). Vakulenko and Livshits $(1970$, plate III, figs. 13,14$)$ recorded single specimens of
Tilia pollen from the Firkanten Formation and the Renardodden (cf. Table 1 of Kvacek et al., 1994, where they are dated as early Paleocene and late Eocene, respectively).

Corsinipollenites

Large triporate pollen from the Onagraceae are found in many Oligocene assemblages in northern Europe.

Ericipites (plate IV, 1-14)

These tetrads are usually thought to be Ericaceous. This family was probably present in the Arctic Tertiary although there is no firm evidence from megafossils.

\section{Trudopollis (plate XII, 24-31)}

Manum (1962) created three new species of this form-genus of Pflug's and commented on their affinity. Certainly they are unlike any modern pollen and represent a large group of extinct plants. They are well preserved, and there is no reason to think they are reworked at Site 908.

\section{COMPARISONS TO OTHER NORTHERN FLORAS}

It is difficult for us to understand the kind of flora that this assemblage represents because there are no modern equivalents of the ecology, the vegetation, or the light conditions beyond $74^{\circ}$ north paleolatitude (Fig. 8). Furthermore, there are no equivalents in long Cenozoic sections farther south where angiosperm pollen are much more common. A temperate climate with about four months of reduced light and even darkness each year would surely demand a special physiology and lifestyle for its inhabitants. We can be sure that the land source adjacent to the Hovgård microcontinent had lowland forested swamps with a high humic productivity. Dominance of bisaccate pollen and very rare angiosperm pollen indicate that the forest was coniferous, composed of Pinus species and other genera closely related to modern Tsuga, Picea, and Taxodiaceae (Fig. 7). Plants of these taxa were at that time growing well, $10^{\circ}$ farther south in warm temperate forests (Boulter and Fisher, 1994). Spores show that ferns were also quite common. The coniferous forests may have comprised stands with little understory light in the summer, occupied first by the ferns when an opening appeared or at the edges of open water (Boulter and Fisher, 1994). Present-day Tsuga enjoys cool, dark, humid conditions, or just the kind that can be deduced around the Hovgård Ridge at about $74^{\circ}-77^{\circ} \mathrm{N}$ in the Oligocene to Miocene. The angiosperms had a small role to play in these forests; our painstaking pollen analysis has identified fewer than 10 taxa, each represented by just a few specimens.

Earlier studies suggest that the vegetation of Spitsbergen did not change greatly for at least 25 million years from Paleocene to Eocene times (Manum, 1994). Pollen assemblages described from the Paleocene to Eocene of the Central Basin on Spitsbergen (Manum, 1962; Livshits, 1974), and their contemporary megafossil floras (Schloemer-Jäger, 1958; Schweitzer, 1974; Kvacek et al., 1994), show a prominent and more diverse selection of angiosperms. The present evidence from the Oligocene and Miocene suggests that there was a dominant representation by the conifers and a subordinate angiosperm element throughout the succeeding intervals. After the Terminal Eocene Event, temperatures began to fall, making such high latitudes less attractive for angiosperms. Evidence from Arctic Canada led Basinger et al. (1994) to argue for a decrease in deciduous vegetation in the Neogene.

The middle Oligocene pollen record from the Hovgård Ridge has an interesting equivalent in the assemblage from the Tertiary outlier at Forlandsundet on Spitsbergen (Sarsbukta) studied by Manum (1962). He found this assemblage to be dominated by bisaccates unlike the assemblages from the Central Basin, where inaperturates formed the dominant coniferous pollen group; the Sarsbukta assemblage was also different in having fewer angiosperms, both in terms of diversity and relative frequency, and Tsugaepollenites appeared as 


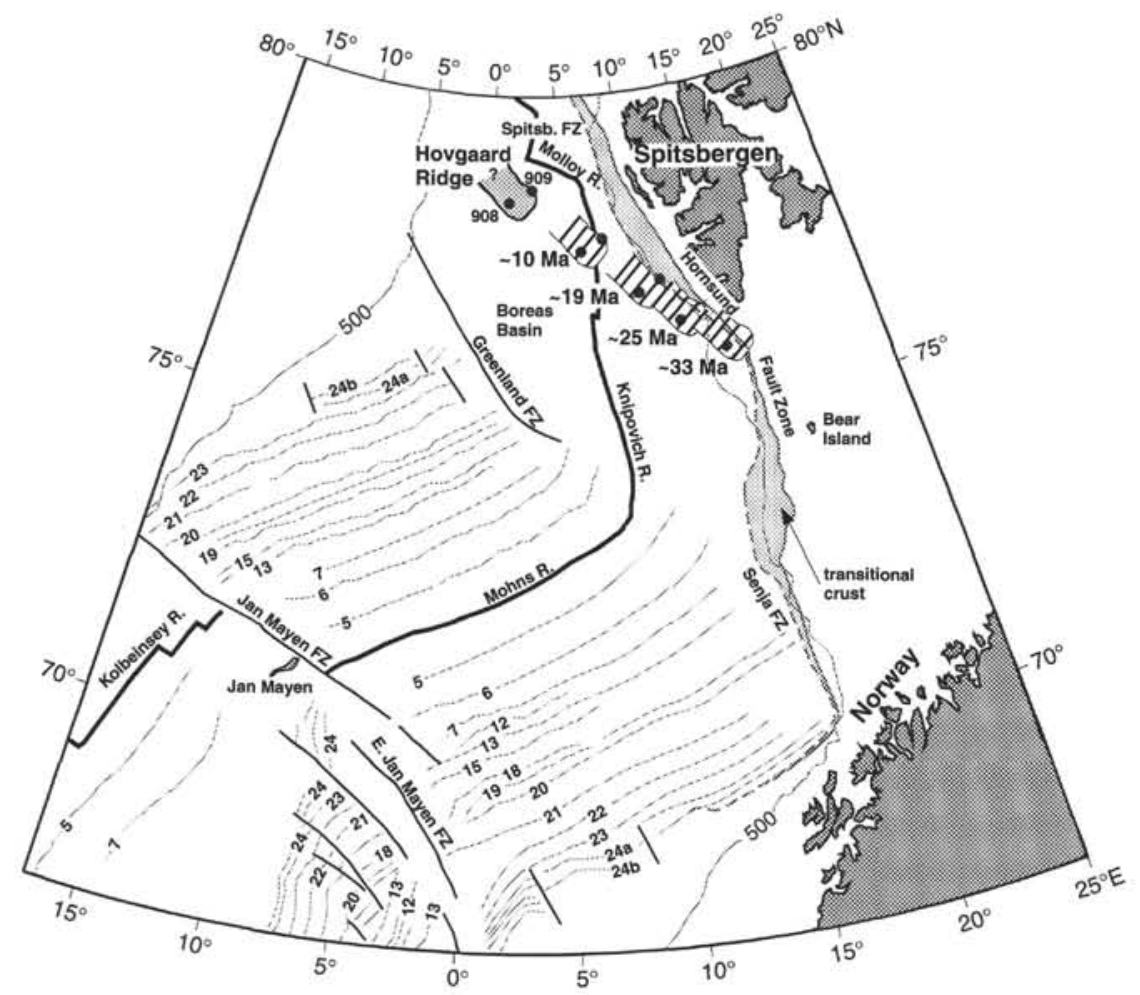

Figure 4. Present-day position of the Hovgård Ridge, Sites 908 and 909 , and their backtracking relative to the Svalbard platform through time to the Eocene/Oligocene transition. Major plate tectonic structures and the paleomagnetic lineations of the Greenland Sea are also shown (modified from Karlberg, 1995). a major new element (representing up to $5 \%$ of the pollen sum), which had not been recorded from the Central Basin. Based on regional geological considerations, the Tertiary sediments at Forlandsundet are generally considered to be younger than any from the Central Basin, but biostratigraphic evidence for their age has been conflicting. Foraminiferal assemblages from the Sarsbukta locality were interpreted as middle or upper Oligocene (Feyling-Hanssen and Ulleberg, 1984), whereas dinoflagellates indicated upper Eocene (Manum and Throndsen, 1986). Recent Sr isotope analyses of foraminifers from the locality have confirmed Feyling-Hanssen and Ulleberg's interpretation, namely 27.5 to $29.5 \mathrm{Ma}$ (Eidvin et al., 1994), which means that the dinoflagellate cysts found by Manum and Throndsen (1986) are reworked. Similar reworking has been reported in a well from the Barents Sea (Eidvin et al., 1994). The pollen assemblage described from Sarsbukta by Manum (1962) is therefore within the same middle Oligocene interval as the Hovgård Ridge sediment and its pollen. Compared with the Paleogene floras in the Central Basin, the younger Sarsbukta and Hovgård Ridge floras are distinguished by a much decimated angiosperm element and the appearance of a Tsuga-related conifer not present in the earlier Paleogene on Spitsbergen.

Tsuga pollen appears in the middle Eocene of the Canadian Arctic (D. McIntyre, pers. comm., 1995). The present evidence from the Oligocene suggests that there was a dominant representation by the conifers throughout the Paleogene in the region of present Spitsbergen, and that their composition underwent some change as seen by the Oligocene appearance of Tsugaepollenites and in the shift from inaperturate to bisaccate dominance. The angiosperm component was considerably decimated from the Eocene to the Oligocene. Two factors were significant in causing declining climatic conditions and taxonomic decimation. One was the global fall in temperature after the Terminal Eocene Event. The other factor was the increase in duration of winter darkness and increasingly severe conditions as the latitude progressively increased.

In the upper Miocene part of the section up to Core 151-908A$19 \mathrm{X}$, all of the pollen taxa present in the Oligocene section continue to be present. This suggests that the vegetational source was fundamentally similar, although at the unconformity we are missing evidence from a period of about 15 to $18 \mathrm{~m}$.y. There is also no evidence of much fluctuation in the proportions of the taxonomic constituents.

It is clear that through the Tertiary, plant evolution and diversification were most active in the tropics and inactive in the high Arctic (Schneider and Kay, 1994). This suggests that there was minimal plant migration at very high latitudes, the Brito-Arctic Igneous Province, the Greenland-Scotland Ridge (Fig. 1), and the Bering bridge being the most northerly routes. In this isolation, with low light levels, the high Arctic would have served as a stagnant genetic pool with little evolutionary activity. Although for four months each year light was available throughout each day, it was only sparse, and for four other months it was not available at all during the winter. So despite environmental change, such as sea-level fluctuations and coastal displacement, evolutionary change is not apparent in this $74^{\circ}-77^{\circ}$ Arctic location from the upper Paleocene to the upper Miocene.

Quite a different situation occurred within about the next $10^{\circ}$ of paleolatitude farther south during the same 40-m.y. interval. Relatively diverse mixed forest, with significant diversity and numbers of angiosperm taxa, is reported from Alaska (Wolfe, 1977), Yukon, Saskatchewan (McIver and Basinger, 1993), offshore Labrador (de Vernal and Mudie, 1989), the Brito-Arctic Igneous Province (Boulter and Kvacek, 1989; Boulter and Manum, 1989), western Russia (Budhantsev, 1992), and Kamchatka (Lavrenko and Fotyanova, 1994). Throughout the Paleogene, the patterns of vegetation in these areas were changing as the result of migration and evolution, unlike the situation to the north.

\section{ACKNOWLEDGMENTS}

We are grateful to co-chief scientist Annik Myhre for data and inspiring discussions about the evolution of the Hovgård Ridge. We thank Astri Dugan, Oslo, for making the preparations and Jim Harris, London, for discussions about the second law of thermodynamics. Ja- 


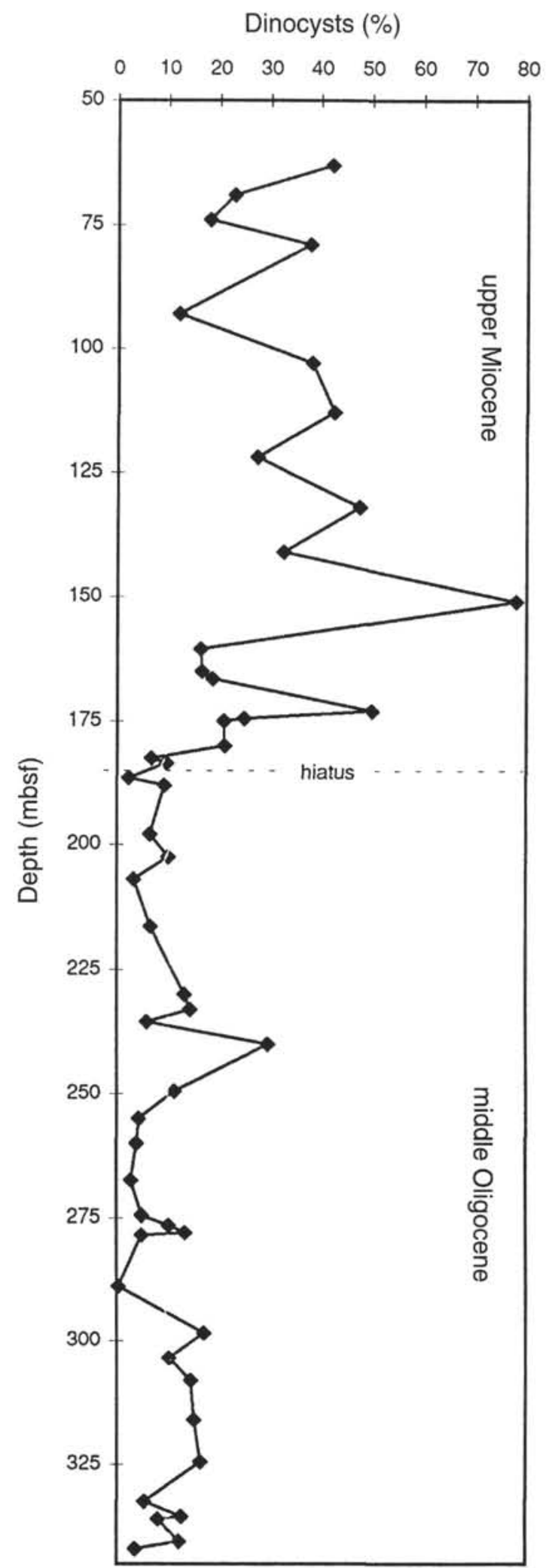

Figure 5. Percentage dinocysts of total palynomorph assemblages through Hole 908A (data down to 150 mbsf from Poulsen et al., this volume).

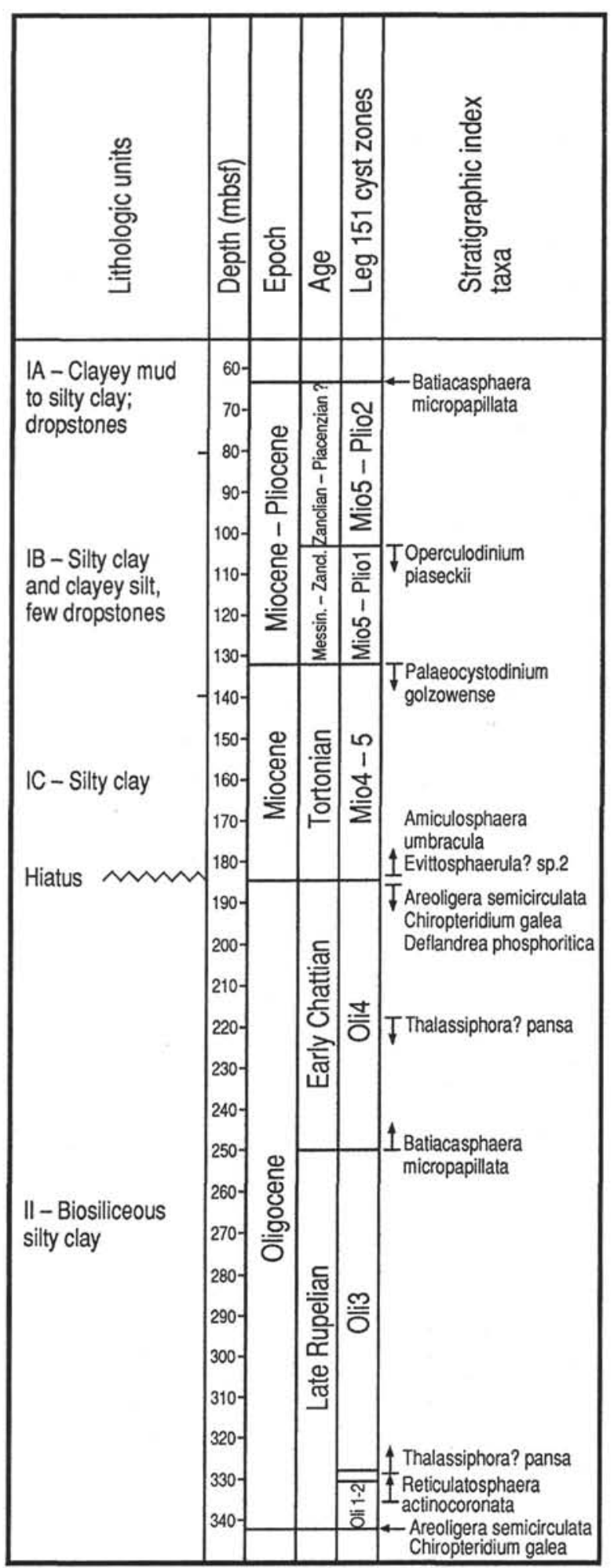

Figure 6. Stratigraphic summary of Hole 908A (biostratigraphy from Poulsen et al., this volume). 


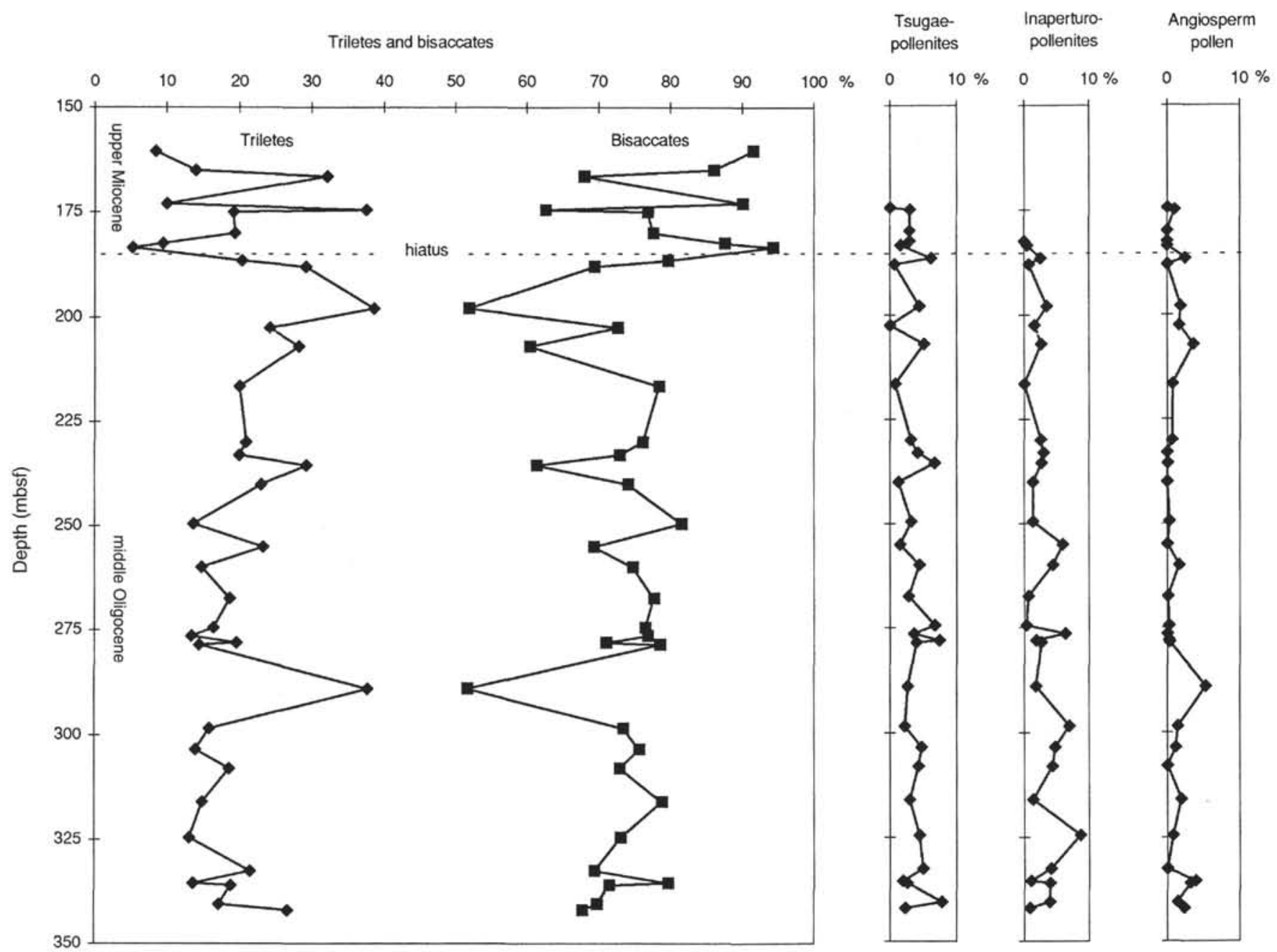

Figure 7. Relative frequencies of main pollen and spore categories in the middle Oligocene and lower upper Miocene of Hole 908A.

kob Skogseid, Oslo, helped with retrieval and designing of paleolatitude map for Spitsbergen; Niels Poulsen, Danish Geological Survey, counted samples from Cores 8 to 17 . SBM is grateful to the Norwegian Research Council for a Senior Scientist Fellowship. We are very grateful to the two referees, D.J. McIntyre and G. Norris, for their helpful and constructive criticisms of the first version of the manuscript.

\section{REFERENCES}

Basinger, J.F., Greenwood, D.R., and Sweda, T., 1994. Early Tertiary vegetation of Arctic Canada and its relevance to paleoclimatic interpretation. In Boulter, M.C., and Fisher, H.C. (Eds.), Cenozoic Plants and Climates of the Arctic: Heidelberg (Springer-Verlag), 175-199.

Boulter, M.C., and Fisher, H.C. (Eds.), 1994. Cenozoic Plants and Climates of the Arctic: Heidelberg (Springer-Verlag).

Boulter, M.C., and Kvacek, Z., 1989. The Palaeocene flora of the Isle of Mull. Spec. Pap. Palaeontol., 42:1-149.

Boulter, M.C., and Manum, S.B., 1989. The Brito-Arctic igneous province flora around the Paleocene/Eocene boundary. In Eldholm, O., Thiede, J., Taylor, E., et al., Proc. ODP, Sci. Results, 104: College Station, TX (Ocean Drilling Program), 663-680.

Budhantsev, L.Y., 1983. Istoria arkticeskoj flory epochi rannego kajnofita. Akad. Nauka: 1-156. [in Russian]

1992. Early stages of formation and dispersal of the temperate flora in the boreal region. Bot. Rev., 58:1-48.
Coffin, M.F., Gahagan, L.M., Lawver, L.A., Lee, T.-Y., and Rosencrantz, E., 1992. Atlas of Mesozoic-Cenozoic reconstructions (200 Ma to Present Day). PLATES Progress Report No. 1-0192, Univ. of Texas Inst. Geophys. Techn. Rep., 122:1-49.

de Vernal, A., and Mudie, P.J., 1989. Late Pliocene to Holocene palynostratigraphy at ODP Site 645, Baffin Bay. In Srivastava, S.P., Arthur, M.A., Clement, B., et al., Proc. ODP, Sci. Results, 105: College Station, TX (Ocean Drilling Program), 387-399.

Eidvin, T., Goll, R.M., Grogan, P., Smelror, M., and Ulleberg, K., 1994. En stratigrafisk undersökelse av övre del av brönn 7316/5-1 (Björnöya Vest) [A stratigraphic study of the upper part of well 7316/5-1 (Björnöya West)]. Norw. Pet. Directorate Contrib., 38:1-81.

Eldholm, E., Myhre, A.M., Sundvor, E., and Faleide, J.I., 1984. Cenozoic evolution of the margin off Norway and Svalbard. In Spencer, A.M., et al. (Eds.), Petroleum geology of the North European Margin: London (Graham and Trotman), 3-18.

Feyling-Hanssen, R.W., and Ulleberg, K., 1984. A Tertiary-Quaternary section at Sarsbukta, Spitsbergen, Svalbard, and its foraminifera. Polar Res., 2:77-106.

Karlberg, T., 1995. A geophysical study of the Hovgaard Ridge [Cand. cient. thesis]. Univ. of Oslo. [in Norwegian]

Kvacek, Z., Manum, S.B., and Boulter, M.C., 1994. Angiosperms from the Palaeogene of Spitsbergen, including an unfinished work by A.G. Nathorst. Palaeontographica B, 232:103-128.

Lavrenko, O., and Fotyanova, L.I., 1994. Some Early Paleocene species from western Kamchatka. In Boulter, M.C., and Fisher, H.C. (Eds.), Cenozoic Plants and Climates of the Arctic: Heidelberg (Springer-Verlag), 315327. 
Livshits, J.J., 1974. Palaeogene deposits and the platform structure of Svalbard. Nor. Polarinst. Skr., 159:1-50.

Manum, S.B., 1962. Studies in the Tertiary flora of Spitsbergen, with notes on Tertiary floras of Ellesmere Island, Greenland, and Iceland. Nor Polarinst. Skr., 125:1-127.

, 1994. The Palaeogene flora of Spitsbergen: implications for Arcto-Tertiary climatostratigraphy. In Boulter, M.C., and Fisher, H.C. (Eds.), Cenozoic Plants and Climates of the Arctic: Heidelberg (Springer-Verlag), 215-223.

Manum, S.B., and Throndsen, T., 1986. Age of Tertiary formations on Spitsbergen. Polar Res., 4:103-131.

McIver, E.E., and Basinger, J.F., 1993. Flora of the Ravenscrag Formation (Paleocene), southwestern Saskatchewan, Canada. Palaeontogr. Can., 10:1-167

Myhre, A.M., and Eldholm, O., 1988. The western Svalbard margin ( $74^{\circ}-$ $80^{\circ}$ N). Mar. Pet. Geol., 5:134-156.

Schloemer-Jäger, A., 1958. Alttertiäre Pflanzen aus Flözen der Brögger-Halbinsel Spitzbergens. Palaeontographica B, 104:39-103.
Schneider, E.D., and Kay, J.J., 1994. Life as a manifestation of the second law of thermodynamics. Math. Comput. Modelling, 19:25-48.

Schweitzer, H.-J., 1974. Die "Tertiaren" Koniferen Spitzbergens. Palaeontographica B, 49:1-89.

Vakulenko, A.S., and Livshits, J., 1970. Palynological characteristics of the Palaeogene deposits of Spitsbergen. NIIGA, Ucenye Zapiski, Paleotol. Biostratigr., 31:39-50. [in Russian]

Wolfe, J.A., 1977. Paleogene floras from the Gulf of Alaska Region. Geol. Surv. Prof. Pap. U.S., 997:1-108.

Date of initial receipt: 5 July 1995

Date of acceptance: 21 December 1995

Ms 151SR-111

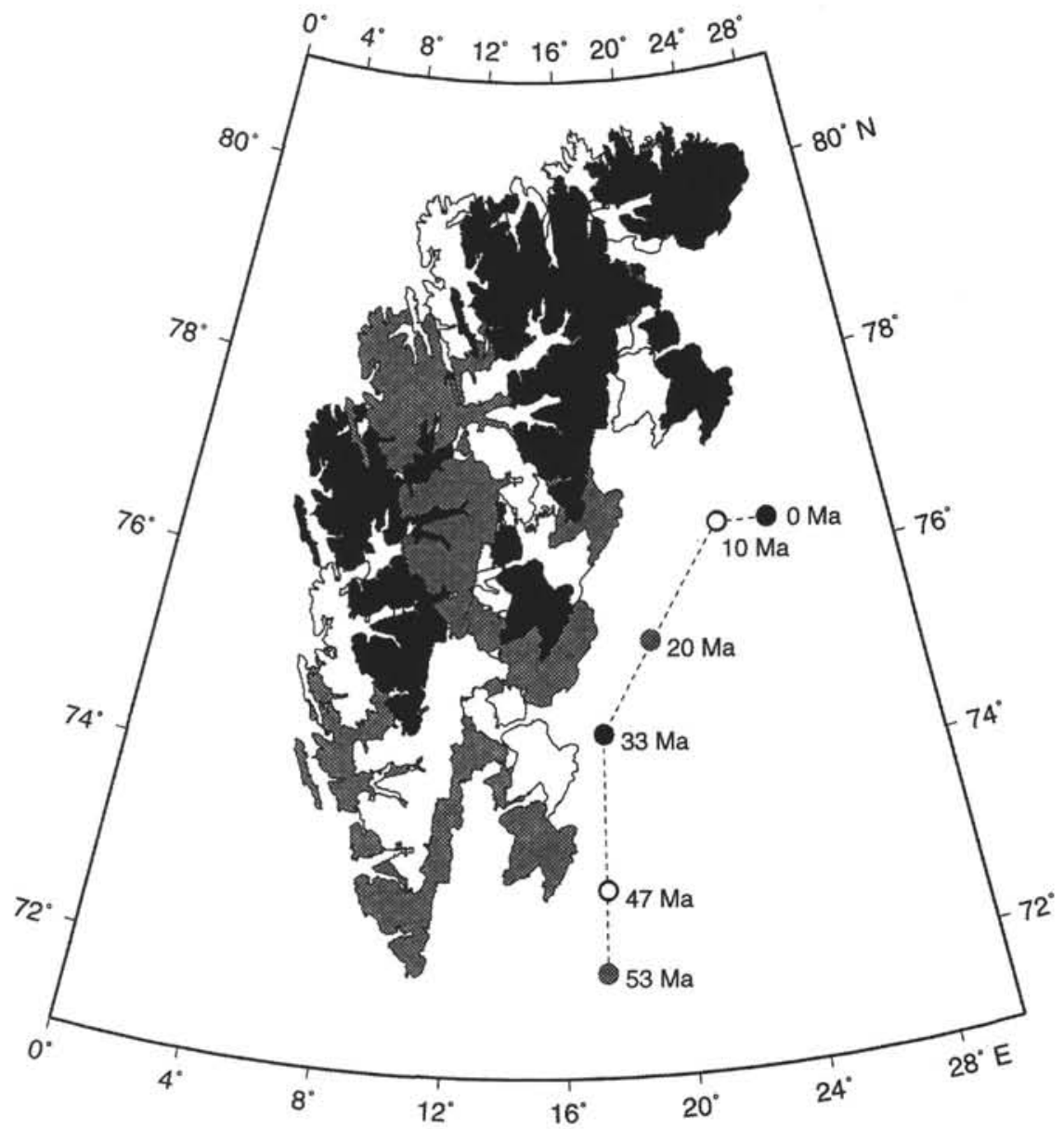

Figure 8. Spitsbergen's drift through time from $53 \mathrm{Ma}$ or the Paleocene/Eocene boundary. The movement is shown by the line drawn through the island of Hopen. From global plate model by Coffin et al. (1992). 